\title{
Residue Analysis of Glyphosate and Aminomethylphosphonic Acid (AMPA) in Soybean Using Liquid Chromatography Coupled with Tandem Mass Spectrometry
}

\author{
Helio A. Martins-Júnior1,2, Daniel T. Lebre3, \\ Alexandre Y. Wang', Maria A. F. Pires ${ }^{1}$ and Oscar V. Bustillos ${ }^{1}$ \\ ${ }^{1}$ Nuclear and Energy Research Institute (IPEN) \\ ${ }^{2} A B$ Sciex \\ ${ }^{3}$ Center for Applied Mass Spectrometry (CEMSA)
}

Brazil

\section{Introduction}

Glyphosate (N-phosphonomethyl glycine) is one of the most widely used pesticide around the world. It is very well known that glyphosate compound rapidly degrades into aminomethylphosphonic acid (AMPA) metabolite (Fig. 1). Glyphosate is a herbicide with a broad spectrum of activity, very effective even on plant roots with little harmful effects on mammals. Its high efficacy, low toxicity and affordable price, when compared with other pesticides, justify the wide utilization in several crops. Due to the low toxicity of glyphosate, the maximum residues levels (MRLs) established around the world are generally greater than the limits for other pesticides. For example, the Codex Alimentarius Commission and the Environmental Protection Agency/USA established the MRL at $20 \mathrm{mg}$ $\mathrm{kg}^{-1}$ for glyphosate in soybean and the National Health Surveillance Agency (ANVISA) in Brazil set the MRL at $10 \mathrm{mg} \mathrm{kg}^{-1}$.<smiles>NCP(=O)(O)O</smiles>

Fig. 1. Degradation of glyphosate (M.W. $169.07 \mathrm{~g} \mathrm{~mol}^{-1}$ ) into its metabolite AMPA (M.W. $\left.111.04 \mathrm{~g} \mathrm{~mol}^{-1}\right)$.

The glyphosate and AMPA's physical and chemical properties such as no volatility, high water solubility, low molecular weight and absence of chromophore groups, make them very difficult to analyze using gas or liquid chromatography techniques with traditional detectors without derivatization. On the opposite, glyphosate and AMPA may be analyzed 
by mass or tandem mass spectrometry, especially by using electrospray ionization, because they are very polar and easily ionized on this technique. However, just a few methods using mass or tandem mass spectrometry coupled with liquid chromatography have been found in the literature for glyphosate and AMPA analysis. In most of published papers, pre and postcolumn derivatization procedures were employed to analyze the compound derivative by fluorescence detection (Sancho et. al. 1996; Hogendoon et. al. 1999). Vreeken and co-workers developed an analytical method to analyze glyphosate, AMPA and glufosinate in water samples using reversed phase liquid chromatography separation after pre-column derivatization with 9-fluorenylmethyl chloroformate (FMOC-Cl) and detection by tandem mass spectrometry (Vreeken et. al. 1998). Bauer and co-workers detected glyphosate and AMPA in water samples using ion chromatography followed by electrospray with single quadrupole mass spectrometry detection. (Bauer et. al. 1999). The ion chromatography separation without derivatization was also used by Granby and co-workers after clean-up on reversed phase column to analyze glyphosate and AMPA through electrospray ionization/tandem mass spectrometric analysis (Granby et. al. 2003). Goodwin and coworkers studied the electrospray negative ion fragmentation pathways of glyphosate and AMPA using an ion-trap mass spectrometer (Goodwin et. al. 2003). Some other methods found in the literature to analyze glyphosate and AMPA include: capillary electrophoresis (Cikalo et. al. 1996), ion chromatography with conductivity detection (Zhu, et. al. 1999), ion chromatography with fluorescence detection (Patsias et. al. 2001), gas chromatography (Hudzin et. al. 2002), immunoassays (González-Martinez et. al. 2005), nuclear magnetic resonance (Deen et. al. 2002) and integrated pulse amperometry (Ji-Ye et. al. 2001).

In this work, we investigated the potential of reversed phase liquid chromatography coupled with electrospray tandem mass spectrometry (LC-ESI/MS/MS) for the quantification of glyphosate and AMPA in soybean spiked samples. In this approach, the compounds were analyzed without derivatization procedures using calibration curves prepared in the matrix, after a simple sample extraction and liquid-liquid partition followed by protein precipitation step with organic solvent to minimize the complexity of the sample. The mobile phase composition and the matrix effects were also investigated to validate the method using a high flow gradient program in a total run time of four minutes for each analyte.

\section{Experimental}

\subsection{Chemicals and standards}

Glyphosate and AMPA standards were obtained from Sigma-Aldrich (Steinheim, Germany). Methanol and dichloromethane HPLC-grade solvents were purchased from J. T. Baker (Deventer, The Netherlands) and ammonium carbonate P.A. was obtained from Merck (Darmstadt, Germany). Purified water was obtained on EASYpure RF System from Barnstead (Dubuque, IA, USA).

The stock solutions of glyphosate and AMPA at $500 \mathrm{mg} \mathrm{L}^{-1}$ were prepared by dissolution of the standards in water. The solutions were maintained at $4{ }^{\circ} \mathrm{C}$ away from light and stocked in polypropylene tubes to avoid adsorption to glass. The calibration standards were prepared in water or blank soybean extracts for the calibration curves.

\subsection{High-performance liquid chromatography}

An Agilent 1100 series (Agilent Technologies, Waldbronn, Germany) system was operated at flow rate of $1.2 \mathrm{~mL} \mathrm{~min}^{-1}$ without split using a Zorbax Eclipse ${ }^{\circledR}$ RDB C8 (Agilent Technologies, 
Waldbronn, Germany) analytical column of $150 \mathrm{~mm} \times 4.6 \mathrm{~mm}$ (i.d.) and $5 \mu \mathrm{m}$ of particle size, maintained at $25 \circ \mathrm{C}$ during the experiments. The injected volume into the LC-MS/MS system was $40 \mu \mathrm{L}$. The binary mobile phase consisted of an aqueous solution with $1.5 \mathrm{mmol} \mathrm{L}^{-1}$ of ammonium carbonate (phase A) and a solution of methanol/water (95/5\%, v/v) with 1.5 mmol L-1 of ammonium carbonate (phase B). The mobile phase initial composition of $65 \% \mathrm{~A}$ and $35 \% \mathrm{~B}(\mathrm{v} / \mathrm{v})$ was held for $0.5 \mathrm{~min}$, followed by linear ramping of $90 \%$ of B over $1.75 \mathrm{~min}$. After the gradient ramping, the mobile phase returned to the initial composition and was held for $1.75 \mathrm{~min}$. The total chromatographic run time was 4.0 minutes.

\subsection{Tandem mass spectrometry}

The experiments were performed using a triple quadrupole mass spectrometer API 4000 (AB Sciex, Concord, Canada) operated in TurbolonSpray ${ }^{\circledR}$ (electrospray) ionization. The capillary voltage was maintained at 5500 and $-4500 \mathrm{~V}$ for positive and negative ion modes, respectively, and the temperature of the turbo heaters was set at $750{ }^{\circ} \mathrm{C}$. Ultrapure air was used as nebulizer gas (GS1) at 55 p.s.i. and heater gas (GS2) at 55 p.s.i. Nitrogen was used as Curtain Gas ${ }^{\mathrm{TM}}$ at 12 p.s.i. in the interface and collision gas (CAD Gas ${ }^{\mathrm{TM}}$ ) at 10 arbitrary units in the LINAC ${ }^{\circledR}$ collision cell (Q2). The declustering potential (DP), collision energy (CE) and collision cell exit potential (CXP) parameters used in the multiple reaction monitoring (MRM) mode are presented in Table 1. The dwell time was set at $150 \mathrm{~ms}$ for each MRM transition, using a pause time of $5 \mathrm{~ms}$. The data were acquired and processed using the Analyst software version 1.4.1 (AB Sciex).

\begin{tabular}{ccccc}
\hline Analyte & $\begin{array}{c}\text { Transition } \\
(\mathrm{m} / \mathrm{z})\end{array}$ & DP $(\mathbf{V})$ & $\mathbf{C E}(\mathbf{V})$ & $\begin{array}{c}\text { CXP } \\
(\mathbf{V})\end{array}$ \\
\hline \multirow{3}{*}{ Glyphosate } & $170>42$ & 50 & 37 & 8 \\
& $170>60$ & 50 & 25 & 10 \\
& $170>88$ & 50 & 15 & 14 \\
\hline \multirow{2}{*}{ AMPA } & $110>63$ & -41 & -26 & -1 \\
& $110>79$ & -41 & -38 & -3 \\
& $110>81$ & -41 & -18 & -3 \\
\hline
\end{tabular}

Table 1. Optimized MRM detection parameters.

\subsection{Sample preparation}

Organic soybean was purchased in a local market in São Paulo and used as blank samples in recovery experiments. The soybean sample was blended and extracted immediately or stored at $-4{ }^{\circ} \mathrm{C}$. A quantity of $2.0 \mathrm{~g}$ of blended sample was weighted in a $50 \mathrm{~mL}$ polypropylene tube and the extraction was carried out with $20.0 \mathrm{~mL}$ of water and $5.0 \mathrm{~mL}$ of dichloromethane during $60 \mathrm{~min}$ by mechanic agitation with a shaker. After the extraction, the sample was centrifuged during $15 \mathrm{~min}$ at $3000 \mathrm{rpm}$ and an aliquot of $1.0 \mathrm{~mL}$ was transferred into a $15 \mathrm{~mL}$ polypropylene tube followed by addition of $1.0 \mathrm{~mL}$ of methanol for 
protein precipitation. The tube was mixed by vortex during $1 \mathrm{~min}$ and centrifuged at 3000 rpm during $15 \mathrm{~min}$. Prior to analysis, the samples were 50 times-fold diluted by mixing 20 $\mu \mathrm{L}$ of the aqueous extract into a $2 \mathrm{~mL}$ chromatographic vial with $980 \mu \mathrm{L}$ of water. An injection volume of $40 \mu \mathrm{L}$ of sample was injected into the LC-MS/MS system.

\subsection{Validation of the method}

The method was validated according to the European Community guidelines (2002/657/EC). Four experiment batches of spiked and blank samples were analyzed to evaluate the performance of the method. These batches were analyzed in four consecutive days with a total of 83 soybean samples. The spiked levels were 0.2 and $0.6 \mathrm{mg} \mathrm{kg}^{-1}(n=18)$, $0.4 \mathrm{mg} \mathrm{kg}^{-1}(n=28)$ and, 0.8 and $2.0 \mathrm{mg} \mathrm{kg}^{-1}(n=3)$. Thirteen blank samples were also analyzed. The results for glyphosate and AMPA recoveries are shown in the Tables 2 and 3 , respectively. In the Table 4, the results from the four validation days were pooled to evaluate the interday recovery and precision.

\begin{tabular}{|c|c|c|c|c|c|}
\hline Batch/Day & $\begin{array}{l}\text { Spike Level } \\
\text { (mg kg-1) }\end{array}$ & $\begin{array}{c}\text { Recovery } \\
(\%)\end{array}$ & $\begin{array}{l}\text { SD } \\
(\%)\end{array}$ & $\begin{array}{c}\text { RSD } \\
(\%)\end{array}$ & $n$ \\
\hline \multirow{5}{*}{1} & 0.2 & 88.1 & 11.5 & 13.0 & 6 \\
\hline & 0.4 & 93.0 & 8.3 & 9.0 & 6 \\
\hline & 0.6 & 94.9 & 5.7 & 6.0 & 6 \\
\hline & 0.8 & 102.4 & - & - & 1 \\
\hline & 2.0 & 91.6 & - & - & 1 \\
\hline \multirow{5}{*}{2} & 0.2 & 76.9 & 9.9 & 12.9 & 6 \\
\hline & 0.4 & 89.2 & 8.1 & 9.0 & 6 \\
\hline & 0.6 & 85.8 & 6.1 & 7.1 & 6 \\
\hline & 0.8 & 89.7 & - & - & 1 \\
\hline & 2.0 & 89.9 & - & - & 1 \\
\hline \multirow{5}{*}{3} & 0.2 & 73.9 & 7.9 & 10.8 & 6 \\
\hline & 0.4 & 80.9 & 7.4 & 9.2 & 6 \\
\hline & 0.6 & 85.1 & 4.5 & 5.3 & 6 \\
\hline & 0.8 & 84.2 & - & - & 1 \\
\hline & 2.0 & 85.7 & - & - & 1 \\
\hline 4 & 0.4 & 109.1 & 6.6 & 6.1 & 10 \\
\hline
\end{tabular}

Table 2. Recovery results of glyphosate in spiked soybean samples. 


\begin{tabular}{cccccc}
\hline Batch/Day & $\begin{array}{c}\text { Spike Level } \\
(\mathbf{m g ~ k g - 1 )}\end{array}$ & $\begin{array}{c}\text { Recovery } \\
\mathbf{( \% )}\end{array}$ & $\begin{array}{c}\text { SD } \\
\mathbf{( \% )}\end{array}$ & $\begin{array}{c}\text { RSD } \\
\mathbf{( \% )}\end{array}$ & N \\
\hline & 0.2 & 93.1 & 7.7 & 8.3 & 6 \\
1 & 0.4 & 95.5 & 5.5 & 5.8 & 6 \\
& 0.6 & 87.9 & 7.5 & 8.5 & 6 \\
& 0.8 & 78.3 & - & - & 1 \\
& 2.0 & 91.1 & - & - & 1 \\
\hline \multirow{2}{*}{2} & 0.2 & 87.7 & 12.8 & 14.5 & 6 \\
& 0.4 & 85.8 & 8.0 & 9.3 & 6 \\
& 0.6 & 95.6 & 8.3 & 8.7 & 6 \\
& 0.8 & 85.7 & - & - & 1 \\
& 2.0 & 91.8 & - & - & 1 \\
\hline & 0.2 & 88.2 & 4.9 & 5.5 & 6 \\
& 0.4 & 73.9 & 4.2 & 5.7 & 6 \\
& 0.6 & 81.3 & 6.1 & 7.5 & 6 \\
& 0.8 & 93.1 & - & - & 1 \\
& 2.0 & 89.9 & - & - & 1 \\
\hline & 0.4 & 94.0 & 5.6 & 6.0 & 10 \\
\hline
\end{tabular}

Table 3. Recovery results of AMPA in spiked soybean samples.

\section{Results and discussion}

Glyphosate and AMPA might be ionized in both positive and negative ionization modes, by addition or loss of proton, respectively, with electrospray technique. However, for quantitation purposes using the MRM experiments, glyphosate and AMPA's higher sensitivity were achieved at positive and negative ion modes, respectively. For this reason, the samples were injected twice into specific methods for each analyte. The Figure 2 shows the positive and negative MS/MS scans acquired for glyphosate and AMPA, respectively. The MRM methods were optimized using three MRM transitions for each analyte, where, one transition was employed for quantification purposes and the two other transitions for confirmation. For quantification, the transitions of $m / z \quad 170>88$ and $110>79$ were used for glyphosate and AMPA, respectively. The selected confirmation transitions for glyphosate were $m / z 170>60$ and 170>42, and the transitions of $m / z 110>63$ and $110>81$ were used for AMPA.

Due to the strong interactions of glyphosate and AMPA with the free silanol groups from stationary phase, the better buffers used in the chromatographic elution were the ones at high $\mathrm{pH}$. The Figure 3 shows the final chromatographic condition obtained by using ammonium carbonate as mobile phase buffer. 

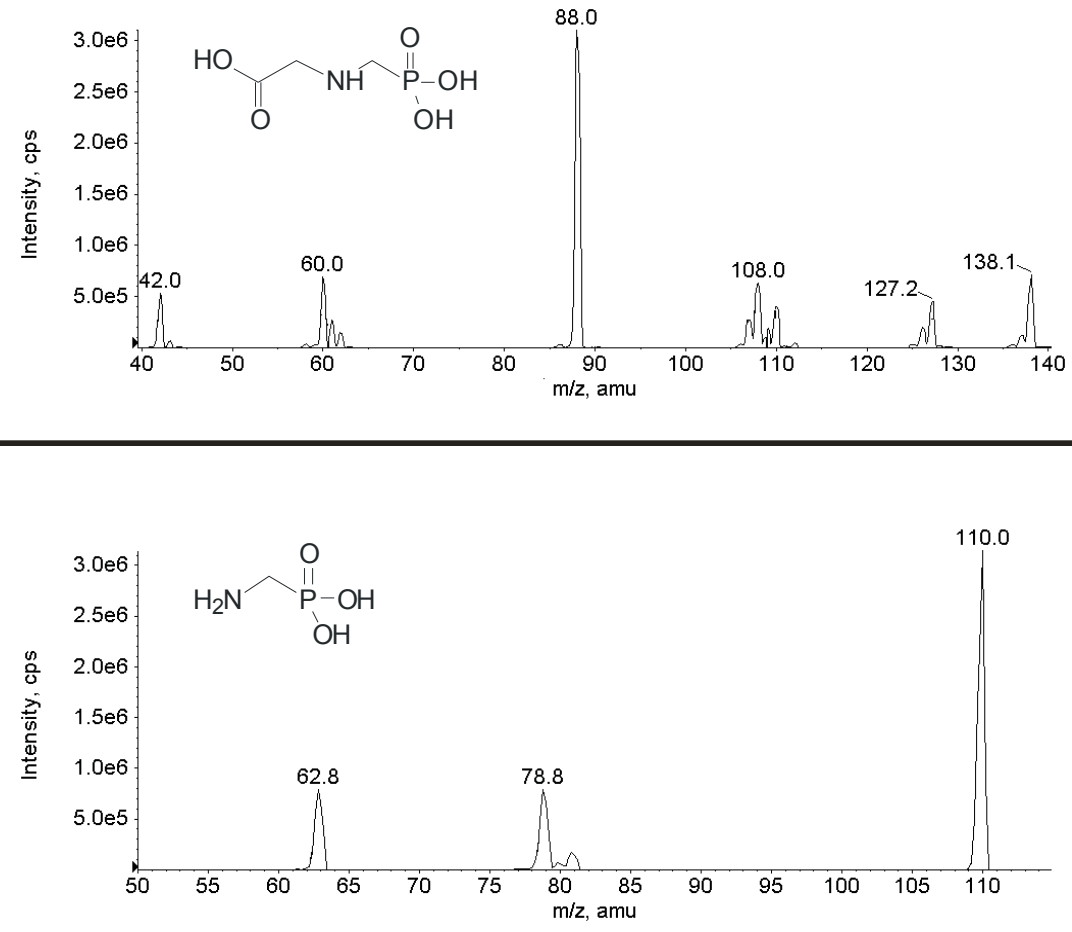

Fig. 2. Positive and negative product ion scan spectra (MS/MS) obtained for glyphosate (on the top) and AMPA (on the bottom).

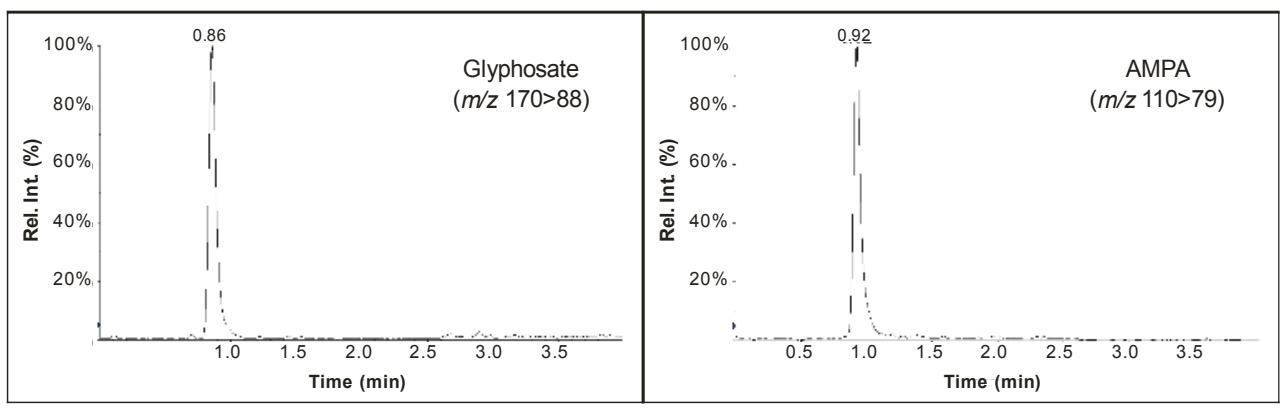

Fig. 3. Chromatographic condition used for glyphosate and AMPA determination.

The sensitivity of the analytes was better when high chromatographic flow was applied. Even when the chromatographic start to run with $65 \%$ of aqueous phase, no loss of ionization efficiency was observed and this solvent composition provided the best analytes peak shape. This better compromise obtained between sensitivity and consumed time of analysis was 
reached producing column pressure smaller than 200 bar. Because of the low retention time of the analytes on the reversed phase some samples were also analyzed using direct flow injection analysis (FIA) into the tandem mass spectrometer without the C8 analytical column to verify a possible ionization signal's suppression or enhancement. The results depicted worse peak shapes and lower recoveries because the matrix signal suppression. Therefore the reversed phase $\mathrm{C} 8$ column used was important to remove some non-polar background compounds from the mobile phase and matrix and enhance the performance of the method.

\subsection{Matrix effect}

Three different solvents were applied to protein precipitation of the dirty extracts obtained from the soybean aqueous extraction: acetone, acetonitrile and methanol. The use of acetone and acetonitrile solvents decreased the recovery of the analytes probably because of the coprecipitation of the analytes with the soybean proteins. The best recoveries for glyphosate and AMPA were obtained using methanol as solvent, however, the application of protein precipitation was not enough to eliminate the matrix interference and a little signal suppression was observed in both analytes detection. The solid phase extraction and the liquid-liquid partition were also unsuccessfully applied to samples clean-up but the ion suppression was not completely avoided. The Figure 2 shows a blank sample extracted ion chromatograms obtained using the post-column infusion method for matrix effects evaluation.

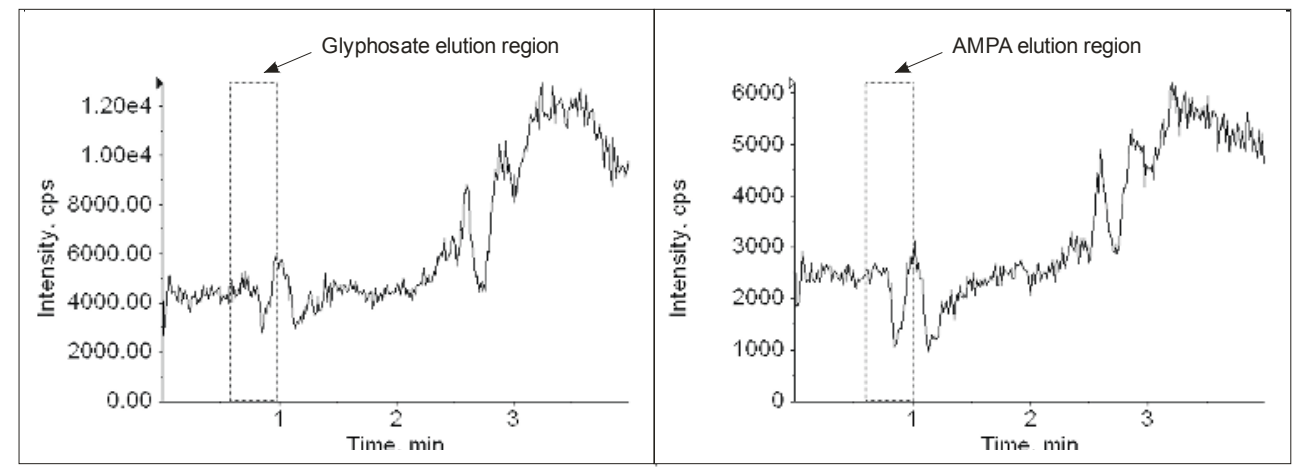

Fig. 4. MRM signals obtained for post-column infusion of glyphosate (left) and AMPA (right). The shaded portions shows the signal suppression for the compounds at their retention times.

Although glyphosate and AMPA detection have been showed noticeable signal suppression effects even after liquid-liquid partition and protein precipitation as showed in Figure 4, the large dilution volume applied to the samples was effective to minimize this effect in the electrospray ion source. In order to solve the matrix effect interference, the analytes were quantified using matrix-matched calibration standards. The standards of the compounds were prepared by dilution of the analytes in soybean blank sample extracts at the concentrations of $0.1,0.2,0.5,1.0,1.5$ and $3.0 \mu \mathrm{g} \mathrm{L}^{-1}$.

\subsection{Recovery and performance}

Although glyphosate and AMPA with their low molecular weight and high polarity provide less sensitivity than other pesticide compounds analyzed in LC-MS/MS, low limits of 
detection were reached. As glyphosate and AMPA have high solubility in water (up to 12 $\mathrm{mg} \mathrm{L}^{-1}$ ), the aqueous extraction was applied successfully to extract these analytes from the soybean spiked samples. The liquid-liquid partition with dichloromethane and the protein precipitation were used to purify the sample extracts yielding the recovery results presented in the Tables 2, 3 and 4 .

\begin{tabular}{cccccc}
\hline Compound & $\begin{array}{c}\text { Spike Level } \\
\left(\mathbf{m g ~ k g}^{-1}\right)\end{array}$ & $\begin{array}{c}\text { Recovery } \\
(\mathbf{0})\end{array}$ & $\begin{array}{c}\text { SD } \\
\mathbf{( \% )}\end{array}$ & $\begin{array}{c}\text { RSD } \\
(\mathbf{\%})\end{array}$ & $\boldsymbol{n}$ \\
\hline \multirow{3}{*}{ Glyphosate } & 0.2 & 79.6 & 9.8 & 12.2 & 18 \\
& 0.4 & 109.1 & 6.6 & 6.1 & 28 \\
& 0.6 & 88.6 & 5.4 & 6.1 & 18 \\
& 0.8 & 92.1 & - & - & 3 \\
AMPA & 2.0 & 89.0 & - & - & 3 \\
\hline & 0.2 & 89.7 & 8.5 & 9.4 & 18 \\
& 0.4 & 94.0 & 5.6 & 6.0 & 28 \\
& 0.6 & 88.3 & 7.3 & 8.2 & 18 \\
& 2.0 & 85.7 & - & - & 3 \\
\hline
\end{tabular}

Table 4. Pooled recovery results for glyphosate and AMPA in spiked soybean samples.

Considering the pooled results presented in the Table 4, the recoveries data for $0.2,0.4$ and $0.6 \mathrm{mg} \mathrm{kg}-1$ were between 79.6 and $109.1 \%$ with relative standard deviation (RSD) smaller than $12.2 \%$ for both analytes. According to the European Community Directive 2002/657/EC, for analyte recovery level higher than $0.01 \mathrm{mg} \mathrm{kg}^{-1}$, the recovery percent level should be between 80 to $110 \%$.

The decision limit (CCa) and detection capability (CC $\beta$ ) established by the EC/657/2002 were, respectively, 0.03 and $0.05 \mathrm{mg} \mathrm{kg}^{-1}$ for glyphosate and 0.03 and $0.06 \mathrm{mg} \mathrm{kg}^{-1}$ for AMPA. These limits were calculated using the following equations based on the interday data set results presented in the Table 4:

$$
\begin{gathered}
\mathrm{CCa}=\frac{\left[\left(\mathrm{y} \_ \text {intersec }+2.33 \mathrm{stdev} \mathrm{y} \_ \text {intersec }\right)-\mathrm{y} \_ \text {intersec }\right]}{\text { slope }} \\
\mathrm{CC} \beta=\frac{\left[\left(\mathrm{y} \_ \text {intersec }+2.33 \mathrm{stdev} y \_ \text {intersec }+1.64 \mathrm{stdev} \text { y_intersec }\right)-\mathrm{y} \_ \text {intersec }\right]}{\text { slope }}
\end{gathered}
$$

The recovered samples curves showed correlation coefficients higher than 0,9885 for both analytes at the studied spike levels.

Considering the low retention time of the compounds in reversed phase columns, three $\mathrm{m} / \mathrm{z}$ transitions were monitored to enhance the reliability of the data and avoid false positives. The Figure 5 shows the zoomed in extracted ion chromatograms for glyphosate and AMPA at three MRM transitions in spiked sample of $0.4 \mathrm{mg} \mathrm{kg}^{-1}$. 


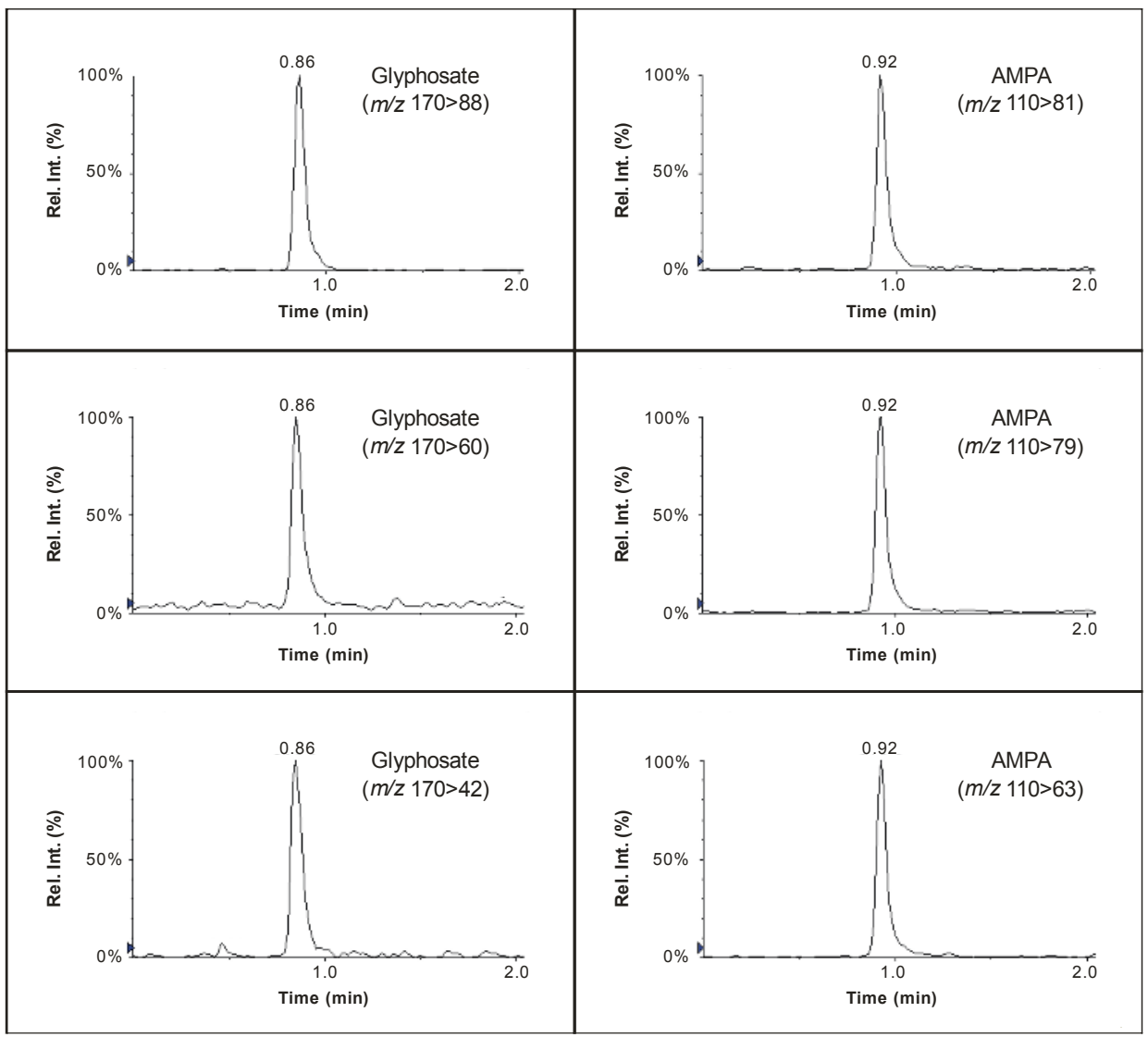

Fig. 5. Extracted ion chromatograms for glyphosate (left) and AMPA (right) for the three MRM transitions used in the method.

The calibration was performed using external matrix-matched calibration solutions at concentration range from 0.1 to $3.0 \mu \mathrm{g} \mathrm{L}^{-1}$. For glyphosate $(\mathrm{m} / \mathrm{z} 170>88)$ and AMPA $(\mathrm{m} / \mathrm{z}$ $110>79)$, the correlation coefficients $\left(r^{2}\right)$ calculated by weighted regression $(1 / x)$ were 0.9991 and 0.9998 , respectively, and the slopes of the calibrations performed on the matrix-matched standards were smaller than those obtained on the solvent standards.

\section{Conclusion}

An alternative methodology for the determination of glyphosate and AMPA residues in soybean with simpler sample preparation, fast chromatographic analysis and sensitive detection was presented. The method's sensitivity and specificity is suitable to meet the limit of residues established in most of the countries as a reliable strategy to evaluate the presence of glyphosate and its major metabolite in soybean samples. The method was developed and validated to spiked organic soybean samples according to the 2002/657/EC. 
The methodology presented in this work improves and simplifies the throughput in glyphosate and AMPA routine analysis, especially by exploring the power of liquid chromatography for quantitation analysis with the sensitivity and confidence of electrospray tandem mass spectrometry. These presented results suggest that this technique may be used with the same purpose for analyzing these compounds residues in other matrices such as: corn and cotton, due to the wide application of the glyphosate on the several crops.

\section{References}

Abdullah, M. P.; Daud, J.; Hong, K. S. \& Yew, C. H. (1995). Improved method for the determination of glyphosate in water. Journal of Chromatography A, 697, 1-2, (April 1995) 363-369, ISSN 0021-9673.

Bauer, K. H.; Knepper, T. P.; Maes, A.; Schatz, V. \& Voihsel, M. (1999). Analysis of polar organic micropollutants in water with ion chromatography-electrospray mass spectrometry. Journal of Chromatography A, 837, 1-2, (April 1999) 117-128, ISSN 00219673.

Börjesson, E. \& Torstensson, L. (2000). New methods for determination of glyphosate and (aminomethyl)phosphonic acid in water and soil. Journal of Chromatography A, 886, 1, (July 2000) 207-216, ISSN 0021-9673.

Cikalo, M. G.; Goodall, D. M. \& Matthews, W. (1996). Analysis of glyphosate using capillary electrophoresis with indirect detection. Journal of Chromatography A, 745, 1, (September 1996) 189-200, ISSN 0021-9673.

Chang, S. Y. \& Liao, C. H. (2002). Analysis of glyphosate, glufosinate and aminomethylphosphonic acid by capillary electrophoresis with indirect fluorescence detection. Journal of Chromatography A, 959, 1-2, (June 2002) 309-315, ISSN 0021-9673.

Codex Alimentarius Commission, Maximum Residue Limits for Pesticides - CAC/MRL, 1 (2001). Franz, J. E.; Mao, M. K. \& Sikorski, J. A. (1997). Uptake, transpor and metabolism of glyphosate in plants, In: Glyphosate: a unique global herbicide, American Chemical Society Monograph 189, 143-181, Washington.

Codex Alimentarius Commission website: http://www.codexalimentarius.net/web/standard_list.do?lang=en

Deen, T. S. A.; Hibbert, D. B.; Hook, J. M. \& Wells, R. J. (2002). Quantitative nuclear magnetic resonance spectrometry - II. Purity of phosphorus-based agrochemicals glyphosate (N-(phosphonomethyl)-glycine) and profenofos (O-(4-bromo-2chlorophenyl) O-ethyl S-propyl phosphorothioate) measured by $1 \mathrm{H}$ and $31 \mathrm{P}$ QNMR spectrometry. Analytica Chimica Acta, 474, 1, (December 2002) 125-135, ISSN 0003-2670.

EEC Council Directive 2002/657/EC, OJ L 221 17.8.2002, pp 8-36.

González-Martinez, M. Á.; Brun, E. M.; Puchades, R.; Maquieira, Á.; Ramsey, K. \& Rubio, F. (2005). Glyphosate immunosensor. Application for water and soil analysis. Analytical Chemistry, 77, 13, (May 2005) 4219-4227, ISSN 0003-2700.

Goodwin, L.; Startin, J. R.; Goodall, D. M. \& Keely, B. J. (2003). Tandem mass spectrometric analysis of glyphosate, glufosinate, aminomethylphosphonic acid and methylphosphinicopropionic acid. Rapid Communications in Mass Spectrometry, 17, 9, (May 2003) 963-969, ISSN 0951-4198. 
Goodwin, L.; Startin, J. R.; Keely, B. J. \& Goodall, D. M. (2003). Analysis of glyphosate and glufosinate by capillary electrophoresis-mass spectrometry utilizing a sheathless microelectrospray interface. Journal of Chromatography A, 1004, 1-2, (July 2003) 107119, ISSN 0021-9673.

Goodwin, L.; Startin, J. R.; Goodall, D. M. \& Keely, B. J. (2004). Negative ion electrospray mass spectrometry of aminomethylphosphonic acid and glyphosate: elucidation of fragmentation mechanisms by multistage mass spectrometry incorporating insource deuterium labeling. Rapid Communications in Mass Spectrometry, 18, 1, (January 2004) 37-43, ISSN 0951-4198.

Granby, K. \& Vahl, M. (2001). Investigation of the herbicide glyphosate and the plant growth regulators chlormequat and mepiquat in cereals produced in Denmark. Food Additives and Contaminants, 18, 10, (October 2001) 898-905, ISSN 1944-0049.

Granby, K.; Johannesen, S. \& Vahl, M. (2003). Analysis of glyphosate residues in cereals using liquid chromatography-mass spectrometry (LC-MS/MS). Food Additives and Contaminants, 20, 8, (August 2003) 692-698, ISSN 1944-0049.

Hogendoom, E. A.; Ossendrijver, F. M.; Dikman, E. \& Baumann R. A. (1999). Rapid determination of glyphosate in cereal samples by means of pre-column derivatisation with 9-fluorenylmethyl chloroformate and coupled-column liquid chromatography with fluorescence detection. Journal of Chromatography A, 833, 1, (February 1999) 67-73, ISSN 0021-9673.

Hudzin, Z. H.; Gralak, D. K.; Drabowicz, J. \& Luczak, J. (2002). Novel approach for the simultaneous analysis of glyphosate and its metabolite. Journal of Chromatography A, 947, 1, (February 2002) 129-141, ISSN 0021-9673.

Ji-Ye Jin, K. S.; Takeuchi, T.; Miwa, T.; Suenami, K.; Takekoshi, Y. \& Kanno, S. (2001). Integrated pulsed amperometric detection of glufosinate, bialaphos and glyphosate at gold electrodes in anion-exchange chromatography. Journal of Chromatography A, 919, 2, (June 2001) 313-320, ISSN 0021-9673.

Kataoka, H.; Ryu, S.; Sakiyama, N. \& Makita, M. (1996). Simple and rapid determination of glyphosate and glufosinate in river water, soil and carrot samples by gas chromatography with flame photometric detector. Journal of Chromatography A, 726, 1, (March 1996) 253-258, ISSN 0021-9673.

Lee, E. A.; Zimmerman, L. R.; Bhullar, B. S. \& Thurman, E. M. (2000). Determination of glyphosate and aminomethylphosphonic acid residues in water by gas chromatography with tandem mass spectrometry after exchange ion resin purification and derivatization. Application on vegetable matrixes. Analytical Chemistry, 72, 16, (July 2000) 3826-3832, ISSN 0003-2700.

Lee, E. A.; Zimmerman, L. R.; Bhullar, B. S. \& Thurman, E. M. (2002). Linker-assisted immunoassay and liquid chromatography/mass spectrometry for the analysis of glyphosate. Analytical Chemistry, 74, 19, (September 2002) 4937-4943, ISSN 00032700 .

Mallat, E. \& Barceló, D. Analysis and degradation study of glyphosate and of aminomethylphosphonic acid in natural waters by means of polymeric and ionexchange solid-phase extraction columns followed by ion chromatography-postcolumn derivatization with fluorescence detection. Journal of Chromatography A, 823, 1, (October 1998) 129-136, ISSN 0021-9673.

National Health Surveillance Agency (ANVISA) web site: http:/ /www.anvisa.gov.br 
Patsias, J.; Papadopoulou A. \& Papadopoulou-Mourkidou, E. (2001). Automated trace level determination of glyphosate and aminomethylphosphonic acid in water by on-line anion-exchange solid-phase extraction followed by cation-exchange liquid chromatography and post-column derivatization. Journal of Chromatography A, 932, 1, (October 2001) 83-90, ISSN 0021-9673.

Sancho, J. V.; Hernández, F.; López, J. F.; Hogendoom, E. A.; Dijkman, E. \& van Zoonen, P. (1996). Rapid determination of glufosinate, glyphosate and aminomethylphosphonic acid in environmental samples using precolumn fluorogenic labeling and coupled-column liquid chromatography. Journal of Chromatography A, 737, 1, (June 1996) 75-83, ISSN 0021-9673.

Vreeken, R. J.; Speksnijder, P.; Bobeldijk-Pastorova, I. \& Noij, Th. H. M. (1998). Selective analysis of the herbicides glyphosate and amonimethylphosphonic acid in water by on-line solid-phase extraction-high-performance liquid chromatographyelectrospray ionization mass spectrometry. Journal of Chromatography A, 794, 1-2, (January 1998) 187-199, ISSN 0021-9673.

Zhu, Y.; Zhang, F. C.; Tong, W. (1999). Determination of glyphosate by ion chromatography. Journal of Chromatography A, 850, 1-2, (July 1999) 297-301, ISSN 0021-9673. 


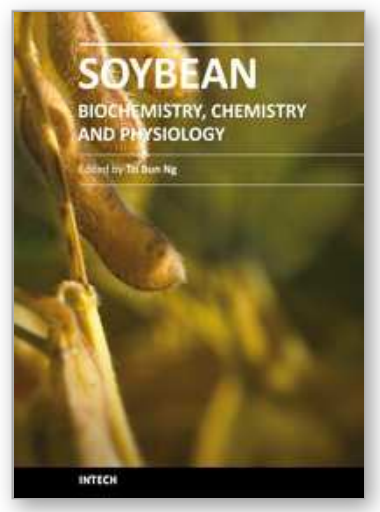

\section{Soybean - Biochemistry, Chemistry and Physiology \\ Edited by Prof. Tzi-Bun Ng}

ISBN 978-953-307-219-7

Hard cover, 642 pages

Publisher InTech

Published online 26, April, 2011

Published in print edition April, 2011

Soybean is an agricultural crop of tremendous economic importance. Soybean and food items derived from it form dietary components of numerous people, especially those living in the Orient. The health benefits of soybean have attracted the attention of nutritionists as well as common people.

\section{How to reference}

In order to correctly reference this scholarly work, feel free to copy and paste the following:

Helio A. Martins-Júnior, Daniel T. Lebre, Alexandre Y. Wang, Maria A. F. Pires and Oscar V. Bustillos (2011). Residue Analysis of Glyphosate and Aminomethylphosphonic Acid (AMPA) in Soybean Using Liquid Chromatography Coupled with Tandem Mass Spectrometry, Soybean - Biochemistry, Chemistry and Physiology, Prof. Tzi-Bun Ng (Ed.), ISBN: 978-953-307-219-7, InTech, Available from:

http://www.intechopen.com/books/soybean-biochemistry-chemistry-and-physiology/residue-analysis-ofglyphosate-and-aminomethylphosphonic-acid-ampa-in-soybean-using-liquid-chromatog

\section{INTECH}

open science | open minds

\section{InTech Europe}

University Campus STeP Ri

Slavka Krautzeka 83/A

51000 Rijeka, Croatia

Phone: +385 (51) 770447

Fax: +385 (51) 686166

www.intechopen.com

\section{InTech China}

Unit 405, Office Block, Hotel Equatorial Shanghai

No.65, Yan An Road (West), Shanghai, 200040, China 中国上海市延安西路65号上海国际贵都大饭店办公楼 405 单元

Phone: +86-21-62489820

Fax: +86-21-62489821 
(C) 2011 The Author(s). Licensee IntechOpen. This chapter is distributed under the terms of the Creative Commons Attribution-NonCommercialShareAlike-3.0 License, which permits use, distribution and reproduction for non-commercial purposes, provided the original is properly cited and derivative works building on this content are distributed under the same license. 